\title{
A "Travessia dos Dantes": alguns relatos etnográficos sobre o cárcere através de um projeto de ensino-extensão universitária no Rio de Janeiro
}

The "Crossing of Dantes": some ethnographic reports on prison through a university teaching-extension project in Rio de Janeiro

\section{Eduardo Rodrigues}

\section{(2) OpenEdition Journals}

\section{Edição electrónica}

URL: http://journals.openedition.org/aa/6671

DOI: 10.4000/aa.6671

ISSN: 2357-738X

\section{Editora}

Programa de Pós-Graduação em Antropologia Social (UnB)

\section{Edição impressa}

Paginação: 246-263

ISSN: 0102-4302

\section{Refêrencia eletrónica}

Eduardo Rodrigues, «A "Travessia dos Dantes": alguns relatos etnográficos sobre o cárcere através de um projeto de ensino-extensão universitária no Rio de Janeiro", Anuário Antropológico [Online], v.45 n. 3 | 2020, posto online no dia 16 setembro 2020, consultado o 28 abril 2021. URL: http:// journals.openedition.org/aa/6671 ; DOI: https://doi.org/10.4000/aa.6671

\section{(c)}

Anuário Antropológico is licensed under a Creative Commons Atribuição-Uso Não-Comercial-Proibição de realização de Obras Derivadas 4.0 International. 


\section{A “Travessia dos Dantes": alguns relatos etnográficos sobre o cárcere através de um projeto de ensino-extensão universitária no Rio de Janeiro}

The "Crossing of Dantes": some ethnographic reports on prison through a university teaching-extension project in Rio de Janeiro

DOI: https://doi.org/10.4000/aa.6671

Eduardo Rodrigues • Universidade Federal Fluminense, Niterói - Brasil

Graduado e Mestre em Geografia pela UFRJ e Doutorando em Antropologia na UFF. É vinculado ao Laboraeorodriguesegmail.com tório de Estudos sobre Conflitos, Cidadania e Segurança Pública da rede INCT-InEAC e professor do Colégio Pedro II.

O presente artigo descreve, desde uma mirada antropológica, as experiências de alguns graduandos em "Direito" e "Segurança Pública e Social" em um projeto de extensão universitária intitulado "Vivências no Cárcere". O projeto objetivou promover vivências e diálogos críticos orientados entre membros da comunidade universitária (e futuros operadores do sistema de justiça brasileiro) e membros da comunidade carcerária fluminense, através de visitas de campo realizadas nas prisões por parceria firmada entre a Universidade Federal Fluminense (UFF) e a Defensoria Pública Geral do Estado do Rio de Janeiro (DPGE). Metodologicamente, o artigo toma o "Inferno" inscrito na "Divina Comédia" de Dante Alighieri enquanto "alegoria" que organiza as experiências do projeto descritas nos "relatórios de campo" dos discentes. Tais relatos, enquanto material usado na construção etnográfica do texto, versam não somente sobre alguns significados apreendidos pelos estudantes, como também os impactos que o projeto trouxe sobre suas visões de mundo. Como resultado, a aproximação entre a obra literária dantesca e os relatos sugeriu estabelecer paralelismos entre as travessias do Inferno e do cárcere, uma vez que a prisão, assim como o Inferno, apareceram enquanto espaços também simbólicos que habitaram simultaneamente os discentes pelo exercício de alteridade sugerido pelo projeto.
This article describes, from an anthropological perspective, the experiences of some undergraduate degree "students of Law" and "Law Enforcement" in a university extension project entitled "Experiences in Prison". The project aimed to promote experiences and critical dialogues between these students (and future members of the Brazilian criminal justice system) and prisoners through fieldwork carried out in prisons by the partnership between Fluminense Federal University and Rio de Janeiro state Office of Public Defenders. Methodologically, the article takes the "Inferno" inscribed in Dante Alighieri's "Divine Comedy" as an "allegory" that organizes the project's observations described in field notes by the students. Such notes, used as the basis for the ethnographic text construction, show not only some meanings apprehended by them during the project, but also its impacts on their worldviews. As a result, the approximation between Dante's literary work and the field notes suggested some parallels between the crossings of "Inferno" and prison, since the prison, like "Inferno", appeared as a symbolic space that simultaneously inhabited the students during the exercise in otherness suggested by the project.

Ethnography. Anthropology. Law. Prison. University extension. 
"Vai-se por mim à cidade dolente, Vai-se por mim à sempiterna dor, Vai-se por mim entre a perdida gente

Moveu justiça o meu alto feitor, Fez-se a divina potestade, mais O supremo saber e o primo amor Antes de mim não foi criado mais Nada senão eterno, e eterna eu duro. Deixai toda esperança, ó vós que entrais".

\section{Prólogo: o preparo da travessia}

Sobre o portal da entrada do Inferno, antes do seu átrio, pode-se ler a inscrição transcrita acima. Ela adverte todas as almas que por aquele caminho cruzam o destino que a elas é reservado. Ao asseverar a dor, o Inferno compreende uma estrutura inscrita fora do tempo, uma vez que ele se propõe eterno, sem volta, sem retorno àqueles que pelas suas portas entram e permanecem. Se ele é eterno, isto significa dizer, por um lado, que a extensão do tempo se faz presente por todo um contínuo para todos aqueles que o experimentam. Ele não admite formas do "estar" mas somente do "ser". Significa dizer também que por romper com o tempo, por sinalizar o eterno, o Inferno é o criador de um regime que se movimenta fundamentalmente por ações no espaço. A distribuição das penas, a alocação dos condenados, o açoite dos demônios, o fogo e o frio que rompem suas almas: todos os tormentos que assolam os danados ganham materialidade através da espacialidade do Inferno, nas diferentes partes que o compõem.

Talvez a descrição mais fantástica das trevas - e que é tomada como referência neste pequeno artigo - se encontre na "Divina Comédia" escrita por Dante Alighieri entre 1307-1319. No prefácio à obra assinado pelo escritor italiano Carmelo Distante, ele argumenta que o grande mérito do gênio de Dante era sua capacidade de pensar por imagens (Alighieri, 1998, p. 15). Escrito todo em verso, a forma assumida pelo poema é capaz de exprimir com perfeição os conteúdos trabalhados pelo autor, sem perder, ao mesmo tempo, a sofisticação estética das imagens que os acompanham. A sofisticação da forma não se encontra somente no mérito de Dante pensar por imagens. Indo um pouco mais além, sua obra é capaz de construir verdadeiras paisagens do Inferno, pois as imagens criadas por ele são dotadas de uma profundidade espacial importantíssima. Em outras palavras, não é exagero afirmar que a descrição minuciosa das formas que marcam os nove círculos infernais transportam o leitor para aquele espaço. É como se o próprio espaço se transformasse em um terceiro personagem a acompanhar os protagonistas na obra literária.

Neste artigo, o Inferno dantesco é tomado enquanto "alegoria" que organiza as experiências de alguns participantes de um projeto de extensão universitária
1 Trecho retirado do "Canto III" do livro "Inferno" da Divina Comédia, de Dante Alighieri. 
intitulado "Vivências no Cárcere". Realizado em dois semestres consecutivos entre os anos de 2017 e 2018, o projeto constituiu-se em uma ação educativa através de parceria firmada entre a Universidade Federal Fluminense (UFF) e a Defensoria Pública Geral do Estado do Rio de Janeiro (DPGE). Seu objetivo principal consistiu em promover vivências e diálogos críticos orientados entre membros da comunidade universitária e membros da comunidade carcerária (Neves, 2018). Em suas duas edições, dezenas de discentes de graduação em "Direito" e "Segurança Pública e Social" da UFF realizaram "vivências" por meio de trabalho de campo realizado no ambiente do cárcere, a partir do acompanhamento das vistorias semanais realizadas pela DPGE em algumas unidades prisionais da região metropolitana carioca.

De modo geral, a aproximação entre a obra literária dantesca e o presente artigo sugere estabelecer paralelismos entre a travessia do Inferno e a travessia do cárcere realizada pelos partícipes. Enquanto, na obra literária, Dante é guiado por Virgílio na travessia do Inferno, nos relatos aqui reunidos eles assumem identidades e papéis multifacetados que correspondem, respectivamente, aos diferentes discentes e coordenadores que atuaram no "Vivências no Cárcere". A travessia empreendida pelos Dantes permitiu a eles diferentes experienciações, através de encontros com leitura de textos acadêmicos e literários sobre a prisão, apresentação de fotos e relatórios, debates e palestras, entre outras atividades formativas ${ }^{3}$. Após os oito encontros da fase de "formação", cada Dante foi conduzido ao cárcere por dois dos nossos Virgílios para que, em seu retorno, suas impressões e estranhamentos fossem compartilhados em um encontro final que contava com a presença de todos os "viventes". Cada discente então, como trabalho final do projeto, foi obrigado a escrever um relatório sobre as impressões da visita guiada com base nos debates feitos previamente na fase de "formação". A travessia de cada Dante foi feita assim por diferentes Virgílios ao longo de nove encontros, assim como os nove círculos que conformam a espacialidade do Inferno na "Divina Comédia".

O tema do relatório final era livre. Isto fez com que a construção de um artigo que desse conta de um universo com reflexões tão diferentes fosse um desafio. Por isso tomei, em primeiro lugar, os textos produzidos pelos estudantes como dados etnográficos. Como alerta Geertz (1989), o texto etnográfico é sempre um texto de interpretação de segunda ou terceira mão, passível de ressignificações e mesmo reinterpretações à luz do olhar que se lança sobre os dados. Para Zenobi (2010), é o contexto que imprime sentido ao dado dentro da pesquisa etnográfica. Os dados antropológicos, diferentemente de outras ciências, não são "colhidos" e nem tampouco "descobertos" - eles são construídos. Este processo parte de escolhas de ordem metodológica que imprimem, já de antemão, um sentido político na pesquisa. E como em qualquer escolha, ela prevê ganhos e perdas para quem escolhe, ou mesmo o privilégio de certos olhares e narrativas sobre outros. Neste sentido, não tenho o menor compromisso em apreender o "sentido" da prisão para cada um dos "viventes", mas talvez compreender alguns (dos muitos) "sentidos", no plural, que a visita ao cárcere trouxe para cada membro do corpo discente. Como assevera Miranda (2001, p. 98), a Antropologia trabalha com a ne-
2 O projeto contou com sete coordenadores e um convidado - estudante universitário e escritor egresso do sistema prisional. Entre os coordenadores, estão um professor da UFF, cinco estudantes de pós-graduação da UFF e da UFRJ e uma defensora pública ligada à DPGE. Entre os discentes, as duas edições do projeto totalizaram aproximadamente vinte estudantes.

3 Cada um dos encontros versou sobre uma temática distinta como objetivo geral de induzir algumas reflexões sobre o cárcere. $O$ objetivo principal da etapa de "formação" foi não somente a preparação para as visitas guiadas pela DPGE, como também a instrumentalização de cada um dos partícipes para a redação do relatório final do projeto. O encontro mediado por mim teve como tema a "escrita etnográfica e a produção de textos", cujo material produzido pelos discentes foi usado como base no presente artigo 
gociação de "verdades" a partir de consensos entre o pesquisador e o pesquisado, pelo confronto entre "verdades" e "mentiras" sempre relativas. Este artigo é não mais que um breve exercício de construir "um texto sobre textos", tendo como matéria-prima aquilo que cada estudante escreveu como trabalho final durante as duas edições do projeto ${ }^{4}$.

Para finalizarmos este prólogo, uma última questão deve ser informada ao leitor. Diante da diversidade de relatos, um fio condutor comum na maioria deles foi a relação entre o "vivente" e o espaço do cárcere. Não só do ponto de vista material, ou seja, do espaço tomado enquanto sistema de objetos e de ações dos sujeitos (Santos, 2001). Mas, sobretudo, do ponto de vista imaterial, que apreende a dimensão simbólica da prisão enquanto indutora de uma teia de significados que se diferenciam para cada um dos discentes. Tomar o espaço enquanto cimento entre blocos assimétricos de relatos possibilitou reforçar mais uma vez a aproximação do artigo com a estrutura narrativa do primeiro livro da "Divina Comédia", que transforma o próprio Inferno em quase um dos protagonistas da história. Sem mais demoras, é tempo de mais uma vez adentrarmos o Inferno. As margens do Aqueronte ${ }^{5}$ estão logo à frente.

\section{Entremeios: alguns sentidos da travessia}

"Respondeu o Mestre: sou um que descendo vou com este vivente, passo a passo, e o inferno todo a ele mostrar pretendo".

Pertencemos a uma geração de corpos que possuem em si marcas de diferentes sequestros. Alguns foram marcados por manicômios ou escolas. Outros tiveram seu sequestro operado pela fábrica. Em todo mundo, cada vez mais corpos passam também pelos sequestros da prisão. Diferentemente do Inferno, qualquer instituição de sequestro que se preze é um espaço que não prescinde do tempo, pois seu objetivo é devolver o indivíduo à sociedade com um comportamento mais adequado, com maior acordo aos seus interesses e expectativas. Não interessa neste contexto nem um pouco a eternidade da alma, mas sim a utilidade do corpo. Para Foucault (2002), as instituições de sequestro são responsáveis por retirar compulsoriamente os indivíduos do espaço social mais amplo, a partir de uma internação de longo período capaz de moldar suas condutas, disciplinar seus comportamentos, ou mesmo dar um novo contorno aos seus pensamentos. Nossos Dantes perceberam tal regime da disciplina logo ao chegar em cada unidade visitada. Assim como no Inferno, as prisões possuem comumente frases logo na sua entrada que sinalizam as expectativas sobre aqueles que por ali entram. No Instituto Penal Plácido de Sá, mais conhecido como "Bangu III”, um Dante vislumbrou na entrada da unidade a inscrição "ressocializar, para o futuro conquistar". Já no Ary Franco, localizado no bairro carioca de Água Santa, o apetite dos homens pela ressocialização conta com um outro estímulo pois, desde a sua entrada, pode-se ler que "Deus faz milagre neste lugar". As frases são diferentes, mas todas de
4 A publicação de parte dos relatórios finais estava inicialmente prevista para ser feita através da DPGE. Tal possibilidade foi exposta informalmente aos estudantes, uma vez que não havia certeza de que o trabalho realmente fosse publicado. A ideia original era que os docentes partícipes do "Vivências no Cárcere" escrevessem ensaios sobre sua experiência no projeto, que seriam reunidos junto a uma seleção de alguns relatórios dos extensionistas para compor a referida publicação. No entanto, o trabalho acabou não sendo publicado e meu ensaio original foi reformulado no presente texto. Como a maior parte dos discentes que participaram do projeto hoje estão ligados ao sistema de justiça, acabei optando por não identificá-los diretamente no texto. Isso se deu a fim de evitar que a exposição de opiniões sobre o cárcere ou outros elementos críticos do seu cotidiano profissional pudessem, de alguma forma, prejudicá-los. Em todo caso, todos os nove relatos usados em meu artigo - bem como os seus respectivos autores são citados nas referências bibliográficas. Como nem todos tinham título, denominei o texto nesses casos com o nome genérico de "relatório de campo".

5 Rio que demarca as fronteiras do Inferno com o seu átrio. Sua travessia é feita pelo barqueiro Caronte, que leva as almas dos danados para a outra margem, rumo ao cumprimento das suas penas eternas. 6 Trecho retirado do "Canto XXIX" do livro "Inferno" da Divina Comédia, de Dante Alighieri. 
alguma maneira carregam consigo algum tipo de justificativa em comum para o sequestro que se realiza por ali de sol a sol, todos os dias do ano.

Em certo sentido, a dimensão do tempo seria responsável por diferenciar os espaços da prisão e do Inferno. Na obra literária, não se trata de um sequestro, mas sim da construção de uma situação de cativeiro eterno, cujo único objetivo é asseverar pura e simplesmente a dor. A prisão, pelo contrário, assinalaria uma condição geralmente momentânea do detento, onde após algum tempo ele seria capaz de ser "reintegrado" à vida em sociedade. Um de nossos Dantes, ao problematizar os sentidos do sequestro, relata o seguinte caso testemunhado na área destinada às celas do "seguro":

Neste momento alguns agentes e o diretor da unidade estavam bem próximos, o que me pareceu forma de intimidação e fez com que eles [os presos] recuassem. Enquanto espaço físico havia muitas "gambiarras" com fios expostos ou cobertos por papel alumínio passando pela parede e teto para chegar aos ventiladores. 0 tamanho da cela não comporta o número de homens, fazendo com que mais da metade deles tenha que dormir no chão em papelão ou espumas. [...] A água apesar de cair nos horários previstos segundo um deles (quarenta minutos, quatro vezes ao dia), não é suficiente para todo o efetivo utilizar nem potável apesar de ser consumida. Nos portões das celas vemos garrafas de dois litros e um ventilador "adaptando" uma forma de refrescar a temperatura dentro das celas superlotadas. Apesar da presença dos guardas e do diretor, na cela seguinte, também denominada "isolamento B", um dos internos fez um apelo maior diretamente ao [Virgílio] do "Monitoramento", muito emocionado, apontando todas as questões que prejudicam o dia a dia: superlotação, água não potável e insuficiente, comida ruim e sem os nutrientes necessários. E relembrou que eles que estão ali são pessoas e não animais e que independente de qualquer coisa têm direitos que, quando não respeitados, vão contra qualquer objetivo de ressocialização.

Já outro Dante, antes mesmo da visita confirmar algumas de suas expectativas sobre o cárcere, confessa que:

no nosso primeiro encontro eu já me senti abalado, sempre soube que a cadeia era um lugar infernal, mas ao ver as fotos e ouvir os relatos dos Virgílios percebi que não sabia nada e que a realidade era muito mais dura do que eu imaginava nos meus piores pensamentos. Superlotação, comidas estragadas, ausência de assistência médica e tantos outros problemas acontecem sob a tutela do Estado e o mesmo não se incomoda, não age, e é isso. Fica tudo por isso mesmo. Saí desse encontro muito consternado, com uma sensação de impotência e revolta indescritível. A pena privativa de liberdade nunca teve o objetivo de ressocializar ninguém, e sim torturar e negar direitos básicos, como alimentação, educação e saúde (...).
7 Celas destinadas aos presos que correm risco de morte dentro da prisão. Falaremos mais detidamente deste espaço um pouco mais à frente. 
Não houve nenhum relato que fosse capaz de vislumbrar o problema da "ressocialização" como justificativa possível para o cárcere. O tempo que diferencia a prisão do Inferno não pareceu oportuno para nossos Dantes, pois ele não permite, em teoria, que o objetivo da "ressocialização" possa ser alcançado. Para os "viventes", os sentidos do tempo prisional, assim como no Inferno, pareceram significar apenas dor e sofrimento, mesmo que eles não sejam eternos. Os dois espaços, se pensarmos nesta direção, acabam estabelecendo algumas ligaduras que tendem mais uma vez a aproximá-los entre si, em especial no tocante à produção de sentidos negativos em comum. A inscrição no portal do Inferno, transcrita no início deste artigo, poderia bem ser transplantada para a entrada de qualquer prisão. A única diferença é que, neste caso, o Diabo seria ao menos mais sincero do que o próprio Estado ao sinalizar, de fato, o destino dos que cruzam o seu caminho. Isto não quer dizer, todavia, que alguns Dantes ainda assim não desejem a prisão, como veremos na seção final do artigo. A existência ou não do cárcere, no seu sentido material e simbólico, está muito além de uma mera funcionalidade ou mesmo desfuncionalidade explícita, como parece ter sido a apreensão geral dos partícipes do projeto.

Seja como for, um outro ponto importante diz respeito a um dos léxicos fundamentais da disciplina: a disposição e o controle rigorosos dos corpos no tempo e no espaço. $O$ poder disciplinar atua tanto através da criação de um espaço analítico para "vigiar o comportamento de cada um, apreciá-lo, sancioná-lo, medir as qualidades ou os méritos” (Foucault, 2010, p. 131), como na construção de um "tempo integralmente útil", através do controle das atividades realizadas pelos indivíduos. Em um dos encontros do projeto, o relato de um Virgílio egresso do sistema prisional fez uma Dante perceber as formas de condicionamento disciplinar pelas quais o detento é exposto:

No dia da conversa com [um Virgílio] na Defensoria [Pública], eu não aguentei nem dez minutos. Não consegui escutá-lo até o final, infelizmente. Ele estava narrando um momento em que em casa, todos dormindo, o pai levantou, acendeu a luz, fez um barulho e [o Virgílio] levantou-se prontamente em posição de "confere", com cabeça baixa. Disse que na prisão todos têm que levantar, caso contrário, apanham. Precisam estar vestidos, acontece de não conseguir vestir a roupa de maneira correta e ter que ficar segurando as calças, por exemplo.

A disciplina age sobre os tempos do banho, da comida, do resguardo, das visitas, do lazer. A disciplina age também sobre o espaço, ao definir e principalmente redefinir os locais onde certas práticas sociais do cotidiano ganham forma. Grande parte do tempo prisional é gasto no espaço da cela, e os significados de certas trivialidades como comer, escovar os dentes, urinar, defecar, tomar banho, dormir ou mesmo amar redefinem o espaço-tempo da intimidade. Este "entranhamento" da disciplina prisional causado pela visita ao cárcere provoca, consequentemente, um "estranhamento" da vida familiar de cada um dos Dantes. Trata-se, neste sen- 
tido, de um exercício de reflexão e produção de conhecimento na dialética entre o "estar lá" e o "estar aqui" (Geertz, 2005) que o projeto proporcionou:

A liberdade que desfrutamos, com todas as intercorrências que podem haver pelo sistema e obrigações, é um enorme privilégio. Escolher quando tomar banho, quando, o que, onde comer, o que vestir, quando dormir. São pequenas liberdades intimamente ligadas à cidadania que é retirada no cárcere. $O$ ser deixa de existir para que se torne objeto de tutela do Estado.

O apagamento do "ser", ou ao menos certas dimensões do "ser", é um mecanismo constituinte do processo de disciplinarização operado por qualquer instituição de sequestro. Ele parte de um regime de controle que arregimenta um corpo de indivíduos a partir da criação de novas identidades, que orbitam em torno da situação do "eu" inscrito no cárcere. Uma dessas identidades diz respeito ao delito cometido pela pessoa. Ele pode ser tomado, ao mesmo tempo, enquanto fator de coesão social entre os presos, ou mesmo como elemento de segregação - se o delito for de algum tipo não aceito pelo "coletivo":

No andar de cima o regime já foi semelhante à visita no semiaberto. Entramos nos dois alojamentos e os presos ficaram circulando à vontade. 0 que me chamou a atenção é que em uma das celas de capacidade para trinta pessoas, haviam cinquenta, enquanto no cárcere logo ao lado que comporta em torno do mesmo número de gente haviam no máximo quinze detentos. Perguntei por que o espaço disponível não era utilizado para desafogar o alojamento superlotado e a resposta que obtive é que os presos novos ficavam sob análise comportamental, separados dos restantes para averiguar para onde cada um seria destinado e até mesmo se permaneceriam naquele presídio. Não consegui perceber até que ponto tal protocolo era para garantir a segurança dos apenados ou [apenas] exercer maior controle sobre os presidiários.

A divisão imposta aos detentos encontra paralelo também no Inferno. Lá, sua estrutura espacial indica precisamente a qual lugar cada danado deve se dirigir para que se faça possível o cumprimento da pena. Os crimes são, de modo geral, divididos em quatro grandes grupos: crimes de "Incontinência" do círculo II ao VI, "Violência e Bestialidade" no círculo VII, "Fraudes" no VIII e, por fim, no círculo mais profundo, se encontram os condenados por "Traição" (Alighieri, 1998, p. 21).

À entrada do segundo círculo, onde de fato começam as penitências ${ }^{8}$, o demônio Minós ouve a confissão das almas e faz a triagem dos condenados, envolvendo-se na sua própria cauda de acordo com o número do círculo destinado ao danado. Por sua vez, no espaço do cárcere, o corpo de Minós é atravessado por uma complexa rede de relações que a todo momento redefinem a fronteira das ilegalidades do dia a dia. Ele não tem uma forma definida, nem tampouco um agente único que encarna em si algum espírito demoníaco encarregado desta res-
80 primeiro círculo é o "Limbo", destinado àqueles sem batismo ou que viveram na Terra antes da vinda de Jesus cristo. 
ponsabilidade. No cárcere são os próprios agentes penitenciários que se encarregam da triagem formal e informal dos presos - mas sempre de acordo com certas regras e condutas organizadas em negociação com o próprio "coletivo" prisional. Sem tal negociação é impossível a gestão de qualquer cadeia, dada as condições de infraestrutura do local e a crescente disparidade entre o número de agentes e a massa de encarcerados.

É o que Carmo (2016) chama de "desenrolo de cadeia", uma categoria que procura descrever a dinâmica das relações de poder estabelecidas entre os presos e os agentes penitenciários na gestão do cotidiano prisional. Para um de nossos Dantes, tal problema tornou-se o ponto central das suas reflexões após a visita:

Com certeza não é apenas o papel que prende. As barganhas, chantagens, penalidades e negociações de vantagens contribuem para a manutenção do presídio e exercício de controle da administração sobre os detentos. 0 futebol, as reuniões ecumênicas, a televisão, o ventilador, a confortável biblioteca e a tão esperada visita íntima em excelentes aposentos. Todas essas ofertas provavelmente servem como instrumentos de dominação e poder. Afinal, existem limites que devem ser respeitados com coisas que não se podem negar para que grandes conflitos sejam evitados. Essa relação tácita como um mecanismo de controle foi explícita quando fora mencionado: "Se a água acabar, a cadeia vai virar".

Por outro lado, são nas profundezas de todo cárcere que talvez o "desenrolo de cadeia" ganhe seu sentido mais dramático. Muitas vezes, ocupar o lugar das trevas da prisão e da memória do "coletivo" é a opção de sobrevivência para certos detentos. Alguns crimes, cometidos em circunstâncias específicas, geralmente sofrem severas retaliações por parte dos outros presos, obrigando alguns indivíduos a ficarem em áreas separadas chamadas de "seguro". Enquanto categoria nativa, novamente Carmo (2016) esclarece que os presos em tais condições reivindicam a segregação no espaço como forma de "seguro de vida", ou seja, como forma de garantir minimamente sua própria integridade física. No geral, são pessoas que cometeram crimes que não mantêm relação direta com um suposto grupo criminoso (geralmente ligado ao tráfico varejista de drogas), a exemplo dos "furtos", "estelionatos”, "agressões domésticas", "estupros” ou ainda presos considerados "milicianos" - em sua grande maioria ex-agentes públicos como policiais, bombeiros, agentes penitenciários, militares, etc. Diferentemente do Inferno, na prisão as formas de triagem não seguem uma lógica identitária única. Em boa parte dos casos, o pertencimento a algum grupo criminoso - com seus códigos de conduta e moralidades próprias - pode informar a disposição dos detentos no sistema prisional. O fato de um preso pertencer ao "Comando Vermelho", "Terceiro Comando Puro" ou ao "Amigo dos Amigos" é uma condição fundamental para sua própria segurança9.

No entanto, outras vezes esta lógica segue um caminho um pouco diferente. A organização espacial do "seguro" se aproxima novamente do Inferno quando
9 Principais grupos armados que operam o comércio varejista de drogas ilícitas no Rio de Janeiro. 
ela assume a forma de outras identidades coletivas que, neste caso, se referem a um estigma, no sentido admitido por Goffman (2008). Em outras palavras, trazer consigo a identidade de "estuprador", "X-9"10, "agressor de mulheres", "pedófilo", "homicida de crianças", entre outras coisas, compreende um conjunto de valores que desestabilizam regras sociais vigentes em um determinado horizonte simbólico. A prática destes crimes acaba por estigmatizar alguns presos, uma vez que eles passam a ser vistos enquanto "desviantes" do ponto de vista das moralidades da cadeia. É comum a "traição" de certos códigos de conduta ou acordos ser punida sumariamente com a morte na prisão. Falo não só da morte do corpo nas suas diferentes formas, mas também de uma pena de morte simbólica, a exemplo dos condenados ao exílio social do "seguro".

De maneira semelhante, não é à toa que no assoalho do Inferno estejam também todos aqueles considerados "traidores". No último círculo, destinado àqueles que traíram seus benfeitores, é o próprio Lúcifer o responsável pela execução das penas, que consistem na devoração eterna dos danados em cada uma de suas três bocas. É lá onde se encontram na obra dantesca as almas decaídas de Judas Iscariote, Brutu e Cássio - cada qual devorada por um das bocas famintas do rei das trevas ${ }^{11}$. No caso da travessia dos nossos Dantes, Lúcifer também os espreita ao assumir outras formas cuidadosamente pensadas na devoração de suas impressões. Os maus agouros que emergem das suas três gargantas são logo percebidos por uma Dante através das nuances do seu cheiro:

Começamos a descer a escada que levava para as celas na parte de baixo. Assim que desci, comecei a sentir um cheiro ruim que vinha de lá. Era um cheiro mais ou menos raro, que achava que nunca tinha sentido, mas que depois de algumas semanas senti de novo numa calçada no centro de $\mathrm{Ni}$ terói e sabia ter sentido antes da visita ao presídio. Era um cheiro azedo (comum em maior ou menor grau a todos os ambientes daquela prisão), e ao mesmo tempo que era abafado, não era porque tinha uma corrente de ar considerável ali. [...] A palavra sinestesia nunca fez tanto sentido para mim. O cheiro - mesmo tendo sido "avisada" sobre desde o primeiro encontro - era indescritível e parecia ter instantaneamente se impregnado em mim. Meu olhar tentava percorrer por toda a estrutura, sem conseguir absorver tudo...

O caminho aos confins das trevas aflige os Dantes não só pela violência do olfato. Diferentes agouros adentram também os olhos e ouvidos dos "viventes" na medida que produzem diferentes afetos que permitem perceber o espaço do "seguro" de outras maneiras também:

a primeira galeria em que fomos foi a das celas do seguro. "Começamos pelo pior", alguém disse. A galeria H é composta por dez celas, cinco de cada lado do corredor. Com portas que não tem espaço entre as grades, existia apenas uma pequena frecha onde os presos colocavam o rosto para poder
10 Categoria nativa para alcaguete.

11 Dante faz referência aqui a Judas Iscariote, que veio a ser o traidor que entregou Jesus aos seus captores por trinta moedas de prata. Arrependido, enforcou-se e acabou condenado ao inferno segundo a tradição cristã. Já Brutu e Cássio participaram da conspiração que levou ao assassinato do imperador romano Júlio César, em 44 a.C. Cássio foi assassinado nos desdobramentos da morte de César, enquanto Brutu, também conspirador, se suicidou dois anos depois. 
enxergar o que estava acontecendo. Eu não estava preparada (sic) praquilo. Quando a pequena cela de número quatro foi aberta, vinte e cinco homens saíram em fila, de cabeça baixa e com as mãos para trás do corpo. 0 primeiro me olhou e gritou: "estamos com fome desde domingo!". À medida que andávamos pelo corredor, mais pessoas nos chamavam, mais atenção era suplicada, "Ei, doutora! Aqui! Por favor!". Não consegui me aproximar, por vezes nem olhar, não por maldade ou coisa do tipo, mas depois de entrar em sua cela e ver a insalubridade, a tortura que era aquilo, eu não sabia se aguentaria ou mesmo se queria ouvir o que tinham a dizer.

Nossa percepção sensível não é a única forma possível de apreender tudo isso. Deixar-se ser afetado pelo espaço - seja ele o cárcere ou o próprio Inferno - resulta também da interação direta com aqueles sujeitos condenados às suas penas. $O$ silêncio do nosso próprio mundo, sitiado pelas fronteiras movediças do "eu", só pode ser rompido pelo verbo que se faz palavra. Não nos referimos a qualquer palavra, mas a palavra-ação que é direcionada ao Outro, ao diálogo que sugere algum sentido para as relações ali estabelecidas entre os sujeitos. Dante percebe isto logo cedo na travessia do Inferno. A sua salvação deriva de um exercício de autorreflexão tributário da compreensão sobre os danados. É o entendimento do "porquê" do sofrimento que sugere a capacidade do poeta em transformar-se e redimir-se de todos os seus pecados. O encontro dos nossos "viventes" com a alteridade, na situação do cárcere, chama atenção para outros estranhamentos possíveis, em especial no que diz respeito à diluição relativa de alguns papéis sociais num determinado contexto situacional:

[...] para ser sincera, em momento algum eu sequer pensei neles enquanto "criminosos" ou em seus crimes, o que foi o mais chocante. Naquele momento isso não fazia sentido algum, pouco importava. Irônico como aqui fora é o que mais importa. São marcados pelos crimes, sua história e sua humanidade são apagadas.

Ou ainda:

Cheguei a conversar com um deles por um período de tempo sobre coisas que não tinham nada a ver com a prisão. Ele foi muito simpático, eu também falei tranquilamente com ele e por fim ele me deu um aperto de mão. Foi um aperto normal, mas que fez parte da minha experiência estranha lá dentro. Talvez para quem comece a ler esse relato esperando um tipo de direção se choque com eu considerar um aperto de mão estranho, mas aquilo foi algo novo para mim, num português transparente, nunca tinha apertado a mão de um "bandido", pelo menos não de um bandido que foi pego.

Enquanto processo, a vivência dos nossos Dantes passa tanto pela maturação de certas reflexões como pela desconstrução de algumas visões de mundo. 
O estranhamento é um resultado esperado deste processo, pois a experimentação da alteridade é sempre pautada pela produção de conflitos. Tomado como fenômeno sociológico, o conflito pode ser lido de diferentes maneiras. Em uma delas, Gluckman (1987) e Van Velsen (1987) apontam que as múltiplas inserções dos indivíduos em diferentes situações sociais são o "motor" responsável pela sua emergência ${ }^{12}$. O cárcere e o "ser" bandido-criminoso que o inscreve estão imersos no tempo. Eles fazem parte de um processo e por isso mesmo são passíveis de mudanças nas formas de representação e experimentação. Quero chamar atenção para o fato dos detentos que interagiram com nossos Dantes não possuírem qualquer essência enquanto "criminosos". Outras possíveis identidades que conformam a complexidade de cada indivíduo são dadas por determinada situação social, evocada através de contextos de diferentes ordens. As expectativas sobre as performances dos sujeitos - bem como as frustrações destas mesmas expectativas - podem ser lidas enquanto manifestações da própria estrutura social onde estamos inseridos.

Dito de maneira um pouco mais clara, meu argumento é que existe uma cadeia expressa em palavras, que pode ser apreendida por diferentes caminhos: na letra fria da lei, nos regulamentos internos das prisões, nas frases que ornamentam suas entradas, no noticiário da televisão, nos filmes, etc. Mas existe também uma cadeia expressa em ações, que podem ser apreendidas, por sua vez, na forma como agem os juízes, na maneira pela qual os presos se comportam, no olhar dos carcereiros, nos constrangimentos implicados aos visitantes dos presos, no tratamento dispensado às rebeliões prisionais, entre outras coisas.

Em uma aproximação com Leach (1998), uma estrutura social pode ser afirmada tanto através de palavras enquanto "mito", ou seja, um "tipo ideal" no sentido weberiano, como também através de ações que ocorrem no tempo, ou seja, enquanto "rito". O cotidiano prisional é todo repleto de distintos mitos e rituais que ora reificam e ora desestabilizam sua estrutura. Neste processo dinâmico, são gerados conflitos que se desdobram pela contínua fricção existente entre as manifestações de mitos e rituais, que tensionam a organização da própria estrutura e os papéis sociais performados pelos sujeitos. Em outras palavras, é possível afirmar que, muitas vezes, os papéis sociais não correspondem às expectativas informadas pela estrutura que os conformam. Nem sempre as palavras concordam precisamente com as ações correspondentes ao seu significado e vice-versa.

Assim, na ausência relativa de idealizações, somos confrontados com um outro problema de ordem fundamentalmente política: a necessidade de negociação permanente dos sentidos. Tal negociação é um dos fundamentos da experiência de alteridade, pois ela permite a relativização de certos valores através do diálogo que estabelecemos com o Outro. Nas relações do cotidiano, é a capacidade de estranhar aquilo que nos é comumente familiar que permite exercitar e ampliar nossa capacidade de autorreflexão (Velho, 1978). Uma passagem transcrita por uma das Dantes retrata com perfeição o referido problema:
12 O presente artigo não sugere tal método para analisar a apreensão dos sentidos do cárcere para os "viventes". Não existem dados etnográficos para tal, nem tampouco espaço para isto em um artigo neste formato. Mas ele sugere, por outro lado, que a análise de certas situações vividas por alguns Dantes contribuíram para a desconstrução de visões essencializadas dos detentos e das próprias prisões, tão comuns no discurso do senso comum e até mesmo em algumas linhagens de pensamento jurídico e acadêmico. 
Um outro momento que não sei descrever ainda, mas que achei estranhíssimo, foi um em que eu estava dispersa no corredor e um dos presos que estava conversando com algumas pessoas da Defensoria [Pública] pediu para eles me pedirem para virar de costas para que ele pudesse mostrar alguma coisa nas costas, em sinal de respeito de não tirar a blusa na minha frente. Eu me virei normalmente enquanto alguns encarcerados da cela que estava então à minha frente me olhavam, ou me olhavam e desviavam o olhar ou abaixavam a cabeça. Alguns falavam coisas que eu não entendia e outros chamavam a atenção deles com um "xiu". Eles respeitam muito as pessoas da Defensoria e para eles eu também pertencia ao órgão. A primeira coisa que refleti foi "como ele não quer me desrespeitar tirando a camiseta na minha frente (atitude natural, ao meu ver) mas talvez me roubasse em outros lugares? O que era respeito para ele?"

Negociar os sentidos é uma forma também de negociar hierarquias. Trata-se de um processo que anima as relações de poder nos espaços entrecortados pelos sujeitos, que só podem acontecer, nesta perspectiva, através de um olhar que leve em consideração também o tempo. O Inferno, por estar fora dele, é assim inegociável. Os sujeitos ali presentes possuem papéis muito bem definidos, que são absolutamente coerentes com uma estrutura que aprisiona sua capacidade de agência. Por outro lado, a prisão é um espaço político por excelência e, precisamente por isso, ela é também um espaço das incertezas. Os papéis sociais e a produção de sentidos no cárcere variam ao sabor da situação social considerada, a exemplo, como vimos, do episódio relatado acima. Os "algozes" e as "vítimas", assim como os afetos que mediam suas interações, possuem um caráter não somente parcial, como também relativo, uma vez que o maior inimigo das essências é o próprio tempo.

Mesmo diante de todas essas questões, a capacidade de relativizar ou mesmo compreender o Outro não levam necessariamente a mudanças nas formas do agir e do pensar. Após tudo o que foi exposto, a que tipo de conclusões nossos Dantes chegaram então sobre o cárcere? O que eles têm a dizer a Virgílio, quando finalmente transpassam o centro da Terra e conseguem chegar à borda do abismo, fora dos domínios das trevas? O ato final da travessia dos Dantes pertence assim ao seu caminho de volta, quando as confissões que tocaram suas "vivências" ao longo do projeto ganham forma através da escrita.

\section{Conclusão: a travessia enquanto exercício de autoconhecimento}

"subimos, ele primo eu segundo, até surgir-nos essas coisas belas, que o céu conduz, por um vazio rotundo; saímos por ali, a rever estrelas"13.
13 Trecho retirado do "Canto XXXIV" do livro "Inferno" da "Divina Comédia" de Dante Alighieri. 
Este pequeno artigo procurou aproximar, desde uma mirada antropológica, um projeto alternativo de ensino do Direito com a Literatura na tentativa de ordenar as experiências de alguns dos seus partícipes. Ao convidarmos o leitor a empreender conosco esta travessia, nossa intenção foi mostrar não só alguns dos significados apreendidos pelos discentes sobre o cárcere, como também possíveis impactos que o projeto trouxe sobre suas visões de mundo. Além disso, diferentemente da obra literária, o propósito do projeto não foi estabelecer uma ordem moral sobre a prisão. Nenhum Virgílio se propôs a isso, já que nenhum Virgílio se propôs a salvar ou mesmo a mostrar os "erros" e "acertos" dos "viventes". O que este artigo procurou reunir foram alguns dos sentidos produzidos por esta experiência, que podem ser também pensados, nesta etapa final, segundo o que Neves (2016, p. 122) denominou de "sensibilidade punitiva", ou seja, certas formas de sentir, pensar e agir que se orientam por uma sensibilidade que aposta na punição como método de controle social. Sob este ponto de vista, duas confissões sintetizam bem os diferentes feixes de pensamento que orbitaram em torno de polos antagônicos de tensão sobre o mesmo problema. Por um lado, um primeiro grupo de Dantes sinalizou certas incertezas quanto às funções da pena e ao próprio papel das prisões na construção de uma sociedade mais "segura". Uma "vivente" desta linhagem concluiu que:

[...] ao entrar [na faculdade], o objetivo era certo: direito por mulheres e em defesa das mulheres. Feminicídio: doze a trinta anos. Estupro: seis a dez anos; ou oito a doze; ou doze a trinta. Estupro de vulnerável: oito a quinze anos; ou dez a vinte; ou doze a trinta. Violência doméstica: três meses a três anos. Abusos, assédio, violência. E cadeia. E números. $O$ abstrato dessa discussão e a urgência do assunto mascara inúmeras questões, desde a prática até a mais subjetiva. Hoje o meu objetivo é incerto, mas sem dúvida mudou de direção. Quando sai alguma notícia de um egresso do sistema prisional que virou pastor, casou-se novamente ou que fez faculdade, as pessoas são tomadas por um sentimento de injustiça, de ódio. Mas por que, se isso seria parte da ressocialização? Na verdade, não entendemos a prisão como um lugar de ressocialização, na maioria das vezes nem mesmo queremos que ela se preste a isso. A prisão objetiva o suplício.

Assim como a prisão, o Inferno também compõe uma das pontas de outro sistema de justiça que não versa sobre homens, mas sim sobre os desígnios de Deus para os infratores da sua lei. Ambos os espaços tendem a se aproximar quanto ao caráter das penas, que asseveram a dor pura e simples como forma de saciar o desejo punitivo humano e divino, sem maiores intermediações ou objetivos de redenção. Se o afastamento deste lugar, no plano dos homens, faz parte do que Elias (1994) denominou de "processo civilizador", é tocante a retomada das prisões e o endurecimento das penas como forma supostamente eficiente de controle do crime. Para Wacquant (2002a; 2002b) e Garland (2008), o declínio do ideal correcionalista nos Estados Unidos e na Europa desde os anos 1970 mudou o próprio 
significado do cárcere. Cada vez mais, as prisões passam de locais destinados à "ressocialização" para a pura "contenção" ou mesmo "exclusão" dos indivíduos. Se pensarmos de um ponto de vista periférico, como o brasileiro, a situação por aqui é ainda mais grave, pois não tivemos nada parecido aos moldes do "Estado de Bem-Estar Social” estadunidense ou mesmo europeu até os dias de hoje.

Mesmo diante de todos esses diagnósticos, a confissão de uma segunda Dante, por outro lado, sintetiza as linhas gerais de uma visão diferente sobre o problema. Nossa "vivente" percebeu o cárcere não somente como algo necessário, mas, acima de tudo, como algo desejável:

Sei que "pagar" não é exatamente o que acontece, sei que nada do que foi feito pode ser desfeito, sei que a prisão não conserta nada, mas nada disso justificaria para mim a decisão de não punir certos crimes, ainda que a punição sirva apenas para desafogar parte da vontade de vingança dos injustiçados. Porém discordo, sinceramente, da visão de que a prisão não deveria existir. Continuo achando esse lugar péssimo e defendo que mudanças para melhor na direção de oferecimento de saúde, educação e higiene devem ser promovidas. Seguramente acredito que muitos não deveriam estar nela, mas não acho que a feiura da realidade carcerária deva ser a única variável ao olhar para esta questão. Estaria escrevendo um relato de mentira se dissesse que não acho digno de algumas pessoas a tal da perda da liberdade como forma de punição e de contenção.

Pode-se apreender muitas coisas por este relato. Chamo atenção para dois elementos fundamentais que se remetem à "sensibilidade punitiva" discente e que se complementam no discurso nativo. Em primeiro lugar, mesmo admitindo o fracasso do cárcere quanto à sua função correcionalista, não é possível para ela a instituição de uma sociedade onde não haja prisões. $O$ encarceramento, como argumenta Foucault (2010, p. 14), marca uma importante modulação no regime das penas enquanto espetáculo público do dia a dia. Com as prisões, a punição brutal do corpo pelas humilhações, açoites, esquartejamentos e incinerações deu lugar ao recolhimento e encobrimento privativo da liberdade. A percepção diária das penas como parte integrante das paisagens humanas vai dando lugar gradualmente a uma consciência abstrata sobre elas, uma vez que as prisões passam a ser a parte menos visível do processo penal.

A construção dessa "consciência abstrata", todavia, vai funcionar como mais um elemento a contar no processo de "construção social da realidade" de cada indivíduo (Berger; Luckmann, 2014). O cárcere possui um lastro considerável no tempo e um amplo espraiamento enquanto tecnologia de controle no espaço. Sua institucionalização é tributária destes dois elementos. Além disso, Douglas (1986, p. 56) argumenta que a legitimação de qualquer instituição passa pela concordância coletiva sobre algum princípio fundante. É evidente que a prisão, enquanto instituição, possui na necessidade de punição este princípio. Neste caso em específico, o que mais chama a atenção é perceber como a adesão a ele mobiliza muito 
mais as paixões do que a razão dos sujeitos. De acordo com o próprio discurso nativo, não é a eficácia das prisões que representa o elemento racional para sua escolha. A justificativa, por outro lado, diz respeito muito mais à satisfação das paixões punitivas da sociedade do que a qualquer outra coisa.

Novamente sob a perspectiva de Berger e Luckmann (2014), é possível afirmar que as prisões fazem parte de uma realidade objetiva a todos nós. Elas estão presentes materialmente no mundo e simbolicamente em diferentes representações sociais - como nos filmes, livros, novelas, desenhos animados, etc. A prisão vai aos poucos sendo interiorizada por cada um dentro do processo de apreensão da nossa realidade individual, que se relaciona, por sua vez, com nossas próprias representações coletivas sobre o cárcere. Retomando mais uma vez Douglas (1986, p. 58), o princípio estabilizador das instituições é fundado não na nossa capacidade coletiva de pensá-las enquanto resultado de um processo social complexo, mas sim enquanto um elemento que se "naturaliza" em nosso cotidiano, como um espaço fora do tempo, assim como é o Inferno na literatura dantesca. Em outras palavras, quanto mais profundamente a prisão se introjeta nos corações e mentes dos sujeitos, menos desafiadas serão suas convenções sociais.

Em complemento a isto, um segundo ponto fundamental do discurso nativo diz respeito a uma dimensão mais ampla do problema: a prisão enquanto desejo. Existe um certo gozo na punição que não está ligado necessariamente ao sadismo. Muito pelo contrário. Se pensarmos de um ponto de vista durkheimiano, a função da punição está baseada principalmente em uma dimensão não racional e emocional das relações sociais. A punição se remete à noção de "solidariedade social" (Durkheim, 2008), uma vez que ela aumenta nosso sentimento de pertencimento a uma comunidade cujas normas e valores morais devem ser respeitados.

Como vimos anteriormente, a experiência do cárcere pode ser apreendida através de diferentes mitos e rituais que preenchem o seu cotidiano de significados. A própria prisão, se pensarmos nos moldes sugeridos por Duff (2003), é parte de um "ritual de punição" que configura uma espécie de linguagem positiva sobre o entendimento moral comum em um determinado grupo. $O$ ritual fortalece o grupo pela punição, pois ele pretende neutralizar todos aqueles que ameaçam suas normas instituídas. No entanto, esses mesmos rituais se conjugam com processos sociais de criminalização muito mais amplos, que transbordam os limites inscritos no próprio cárcere. Todos os detentos sofrem o que Misse (2010) chama de "sujeição criminal", ou seja, a construção social sobre esses sujeitos de uma subjetividade que se reconhece e é reconhecida enquanto criminosa. Através dela, o crime é corporificado como se o seu comportamento ou mesmo a sua "essência" fossem nele baseados, abrindo caminho para que categorias como "bandido" ou "detento" deem conta de um modo supostamente específico de agir, pensar, sentir e ser.

A "sujeição criminal" marca assim uma cisão no tecido social, uma ruptura que permite o desenvolvimento de distintas clivagens morais dentro da ideia homogênea de "comunidade" defendida anteriormente por Durkheim. A "solidariedade social” não é evocada assim para todos os indivíduos, mas somente para aqueles tidos enquanto "iguais", ou seja, uma parte dos "não-bandidos" que 
estão fora da prisão. Em sociedades hierárquicas com estatutos diferenciados no acesso a direitos, como a brasileira (DaMatta, 1979; Santos, 1979; Kant de Lima, 2000; Carvalho, 2002), a punição estreitará simultaneamente laços comuns entre certos segmentos sociais por um lado, como também criminalizará outros grupos sob a chave da "raça", "gênero" e/ou "classe" por outro. O resultado deste processo, por fim, é a produção de uma "solidariedade hostil" (Carvalho; Chamberlen, 2018) que permite aos indivíduos a liberação emotiva de um desejo por maior pertencimento e segurança, sem qualquer questionamento crítico sobre as origens da sua própria insegurança e medo em primeiro lugar.

No frigir dos ovos, a teia de significados que nossos "viventes" construíram sobre o cárcere torna as fronteiras que o delimitam bastante difusas. A prisão, assim como o Inferno, são espaços também simbólicos capazes de habitar simultaneamente cada um de nós - sejamos Dantes ou Virgílios - no nosso cotidiano ritmado pela capacidade de sentir, pensar e agir com o Outro. Na travessia dos Dantes, as aleias que levam ao conhecimento do Inferno podem levar também ao um maior conhecimento sobre nós mesmos. Resta-nos somente estar dispostos a correr este grande risco. 


\section{Referências}

ALIGHIERI, Dante. A divina comédia: inferno. São Paulo: Editora 34, 1998.

BERGER, Peter L.; LUCKMANN, Thomas. A construção social da realidade: tratado de sociologia do conhecimento. Rio de Janeiro: Vozes, 2004.

CARMO, Diego Barros do. Desenrolo de cadeia: um estudo etnográfico sobre punições e castigos dentro do sistema penitenciário fluminense. Monografia (Bacharelado em Segurança Pública) - Universidade Federal Fluminense, Niterói, 2016.

CARVALHO, Henrique; CHAMBERLEN, Anastasia. Why punishment pleases: Punitive feelings in a world of hostile solidarity. Punishment \& Society, 2017. p. 1-18.

CARVALHO, José Murilo de. Cidadania no Brasil: o longo caminho. 3. ed. Rio de Janeiro: Civilização Brasileira, 2002.

COLLET, Carlos. Relato do Projeto de Extensão "Vivências no Cárcere". Trabalho final do projeto "Vivências no Cárcere". Niterói: Universidade Federal Fluminense, 2017. Mimeo.

DAMATTA, Roberto. Você sabe com quem está falando?. In: DAMATTA, Roberto. Carnavais malandros e heróis: para uma sociologia do dilema brasileiro. Rio de Janeiro: Zahar, 1979. p. 139-193.

DOUGLAS, Mary. Como as instituições pensam. São Paulo: Editora da Universidade de São Paulo, 1998.

DUARTE, Camila. Relato do projeto "Vivências no Cárcere". Trabalho final do projeto "Vivências no Cárcere". Niterói: Universidade Federal Fluminense, 2017. Mimeo.

DUFF, Robin Antony. Punishment, Communication, and Community. Oxford: Oxford University Press, 2003.

DURKHEIM, Émile. Da divisão de trabalho social. 3. ed. São Paulo: Martins Fontes, 2008.

ELIAS, Norbert. O processo civilizador. Rio de Janeiro: Jorge Zahar Ed., 1994. v. 1.

FOUCAULT, Michel. A verdade e as formas jurídicas. Rio de Janeiro: NAU editora, 2002.

FOUCAULT, Michel. Vigiar e punir: nascimento da prisão. 38. ed. Petrópolis: Vozes, 2010.

GARLAND, David. A cultura do controle: crime e ordem social na sociedade contemporânea. Rio de Janeiro: Revan, 2008.

GEERTZ, Clifford. A antropologia e o cenário da escrita. In: GEERTZ, Clifford. Obras e vidas: a antropólogo como autor. 2. ed. Rio de Janeiro: Editora UFRJ, 2005. p. 11-39.

GEERTZ, Clifford. Uma descrição densa: por um teoria interpretativa da cultura. In: GEERTZ, Clifford. O saber local: novos ensaios em antropologia interpretativa. Rio de Janeiro: Guanabara Koogan, 1989. p. 13-41.

GLUCKMAN, Max. Análise de uma situação social na Zululândia moderna. In: FELDMAN-BIANCO, Bela (Org.). Antropologia das sociedades contemporâneas. 2. ed. São Paulo: Unesp, 1987. p. 237-364.

GOFFMAN, Erving. Estigma: notas sobre a manipulação da identidade deteriorada. 4. ed. Rio de Janeiro: LTC, 2008.

JÚNIOR, Paulo Roberto. Relatório de Campo. Trabalho final do projeto "Vivências no Cárcere". Niterói: Universidade Federal Fluminense, 2018. Mimeo.

KANT DE LIMA, Roberto. Carnavais, malandros e heróis: o dilema brasileiro do espaço público. In: GOMES, Laura Graziela; BARBOSA, Lívia; DRUMMOND, José Augusto (Orgs.). O Brasil não é para principiantes: carnavais, malandros e heróis, 20 anos 
Eduardo Rodrigues

depois. Rio de Janeiro: FGV, 2000. p. 105-123.

LEACH, Edmund. Sistemas políticos da Alta Birmânia. São Paulo: Edusp, 1998.

LEBRE, Bruna. Relatório de Campo. Trabalho final do projeto "Vivências no Cárcere". Niterói: Universidade Federal Fluminense, 2017. Mimeo.

LEONES, Carolina. Relato. Trabalho final do projeto "Vivências no Cárcere". Niterói: Universidade Federal Fluminense, 2017. Mimeo.

MIRANDA, Ana Paula Mendes de. Segredos e mentiras, confidências e confissões: reflexões sobre a representação do antropólogo como inquisidor. Revista Comum, Rio de Janeiro, v. 6, 2001. p. 91-110.

MISSE, Michel. Crime, sujeito e sujeição criminal: aspectos de uma contribuição analítica sobre a categoria "bandido". Lua Nova, n. 79, 2010. p. 15-38.

MOUFFRON, Yasmin. Relatório de Campo. Trabalho final do projeto "Vivências no Cárcere". Niterói: Universidade Federal Fluminense, 2018. Mimeo.

NEVES, Fernando Henrique Cardoso. Sensibilidade punitiva e a formação jurídico-penal: uma análise empírica. Confluências - Revista Interdisciplinar de Sociologia e Direito, v. 17, n. 2, 2016. p. 117-134.

NEVES, Fernando Henrique Cardoso. Vivências no cárcere: abolicionismos penais e extensão universitária. Dissertação (Mestrado em Sociologia e Direito) - Universidade Federal Fluminense, Niterói, 2018.

OLIVEIRA, Renan. Relato do projeto "Vivências no Cárcere". Trabalho final do projeto "Vivências no Cárcere". Niterói: Universidade Federal Fluminense, 2017. Mimeo.

SANTOS, Wanderley Guilherme dos. Cidadania e Justiça: a politica social na ordem brasileira. Rio de Janeiro: Campos, 1979.

SANTOS, Milton. A natureza do espaço. São Paulo: Edusp, 2001.

TAVARES, Larissa. Relatório de Campo. Trabalho final do projeto "Vivências no Cárcere". Niterói: Universidade Federal Fluminense, 2018. Mimeo.

TEIXEIRA, Júlia. Relatório de Campo. Trabalho final do projeto "Vivências no Cárcere". Niterói: Universidade Federal Fluminense, 2017. Mimeo.

VAN VELSEN, Jaap. A análise situacional e o método de estudo de caso detalhado. In: FELDMAN-BIANCO, Bela (Org.). Antropologia das sociedades contemporâneas. 2. ed. São Paulo: Editora da Unesp, 1987. p. 437-468.

VELHO, Gilberto. Observando o familiar. In: NUNES, Edson de Oliveira (Org.). A aventura sociológica: objetividade, paixão, improviso e método na pesquisa social. Rio de Janeiro: Zahar, 1978. p. 36-47.

WACQUANT, Loïc. A tentação penal na Europa. Discursos Sediciosos (crime, direito e sociedade), ano 7, n. 11, 2002a. p. 9-14.

WACQUANT, Loïc. A ascensão do estado penal nos EUA. Discursos Sediciosos (crime, direito e sociedade). ano 7, n. 11, 2002b. p. 15-42.

ZENOBI, Diego. $O$ antropólogo como espião. Das acusações públicas à construção das perspectivas nativas. Revista Mana, v. 16, n. 2, 2010. p. 471-499. 